\title{
The EU's fledgling society: From deafening silence to critical voice in European constitution making
}

\author{
John Erik Fossum and Hans-Jörg Trenz
}

\begin{abstract}
The European Union is presently at a major crossroads. The Laeken process which launched the EU onto an explicit constitution-making process, has ground to a halt after the negative referendum results in France and the Netherlands. The European Council at its 16-17 June 2005 meeting decided to postpone the ratification process (by then 10 states had ratified and 2 had rejected) and instead issue a period of reflection. These events represent a significant re-politicization of the European integration process. From a research perspective they underline the need to study the dynamic interrelation between the emerging European polity and its social constituency. In this article we provide an analytical model of EUconstitutionalisation in terms of polity building and constituency building, a model that links institutional performance back to public voice and mobilisation. Our focus on determining the character of the EU's emerging social constituency goes beyond the contentious politics approach because it does not only focus on public voice but also provides a research framework for properly understanding the role of public silence.

In empirical terms, this implies looking at the structure of public communication and claims-making in the EU and in the Member States. The European public sphere in relation to constitution making is then our object of analysis. More specifically, we present a research framework that will help us to shed light on the character of the EU's social constituency, as it emerges in dynamic interaction with the process of polity formation.
\end{abstract}


... the democratic debate has focused on the distribution and use of power within a given community rather than on the definition of the community

(Guéhenno 1998: 1

\section{Introduction: The long-expected re-politicization of European integration}

The European Union is presently at a major crossroads. The Laeken process (the Declaration, the Convention and the subsequent Intergovernmental Conference (IGC)) which launched the

EU onto an explicit constitution-making ${ }^{1}$ process, has ground to a halt after the negative referendum results in France and the Netherlands. These negative referenda results have exposed deep discrepancies between what is touted as the political elite's Constitutional Treaty (CT) and the peoples' claims and expectations. At the same time, these results occurred after the Union had introduced more inclusive and participatory measures within the realm of European governance in general and constitution making in particular (cf.

Conventions and popular referenda). The process of EU constitution making has opened a space of societal contention that might constrain further institutional choices and affect the subsequent fate of constitutionalisation itself. Both the range and the scale of this space are unknowns. It is filled with increasingly attentive publics who are included in opinion and will formation processes and - when asked - are ready to express their views with the well known de-legitimating or legitimating effects.

In this article we provide an analytical model of EU-constitutionalisation understood as polity building and constituency building, a model that can also link institutional performance back to public voice and mobilisation. In empirical terms, this implies looking at the structure of public communication and claims-making in the EU and in the Member States. The European public sphere in relation to constitution-making is then our object of analysis. 
The unique experience of EU-constitutionalisation is distinguished from larger processes of global transformation precisely by this strive to combine polity and constituency building within the legal-institutional framework of the European Union. This effort has to contend with two peculiar features of the EU experience: The first is the forging of a nonstate-based supranational entity, and the second is that this type of constitutionalisation takes place within a setting of existing constitutional arrangements. The EU, in its present form, defies conventional conceptions of political order - be it state, regime, or international organisation. It does however constitute a polity of some sort, which is evident in its institutional-constitutional structure; in its range and scope of operations; and in its effects on the Member States. European integration further challenges conventional conceptions of societal order. It affects the 'people of Europe' in their quality as collective actors, who call for participation and in their capacity as 'silent publics'.

The constitution making process is a particularly opportune instance for clarifying the dynamics of social and political integration in Europe, as well as for establishing the prospects for a legitimate and enduring order beyond the nation state. Note that whether adopted or not the CT would only further consolidate the distinguished nature of the European order, and certainly not invent it. A deeper investigation of the polity - society dynamics at this important juncture can also shed light on the sustainability of the structure that the CT would consolidate.

In this article we propose a research framework that will help us to shed light on the character of the EU's social constituency, at it emerges in dynamic interaction with the process of polity formation. We remodel the normative and analytical dimensions that such a research strategy presupposes (the relevant modes of legitimacy and the constitutive feature of the social constituency); we develop several possible developmental trajectories; and we clarify the particular contribution of constitutionalisation to social constituency formation. 
Our aim here is to spell out the requisite categories for such a comprehensive research project, so as to help set the agenda for the proper conceptualisation of European society-building.

\section{Bringing society back in}

Recent events have underlined that European integration cannot be meaningfully reduced to processes of policy-making within selected governance structures. European integration is better seen as an encompassing social and political transformation of the nation-state constellation within the European context. Many analysts see the EU as having heralded in a new and unique socio-political order in Europe. The scope and ramifications of this transformation are still unclear. Thus far students of European integration have mainly focused on elite-driven processes of integration among state actors, EU institutions and invited experts and lobbyists. Reflecting on the limits of this research Imig and Tarrow have noted that: 'we know much more about participation in consultative committees in the five square kilometres of Euroland in Brussels than we do about contention over the effects of their decisions among the 375 million people who have to live with their consequences' (Imig and Tarrow 2000: 7). These authors work from the contentious politics perspective, and are concerned with escaping the limitations that have marked mainstream perspectives on European integration. However, the contentious politics perspective nevertheless also suffers from built-in limitations that our approach seeks to overcome (see below).

Most of the analytical effort that has been expended on European constitution-making has focused on policy and polity transformation. Institutional and normative aspects of the constitutionalisation process have been analysed in considerable depth. ${ }^{2}$ Prominent critics have also denounced the very prospect of a European democratic constitution. ${ }^{3}$ Such analyses have little to tell us about how people conceive of constitution making; neither do they say much about the social 'take’ and perceived legitimacy of a European constitutional construct. 
Sociology has only recently started to focus on how the EU affects the 'peoples of Europe', in their capacity as collective actors who call for participation and in their capacity as 'silent publics', who develop specific attitudes and expectations towards the EU. Instances of Europeanisation of collective action and of public communication within the multi-level governance framework of the EU have been analysed, ${ }^{4}$ but so far this has not shed sufficient light on the social conditions that provide the constraining and/or enabling context for institutional negotiations and normative expectations. Foremost among these social conditions are the visible and audible contentions and claims-making as they spread within the emerging European polity.

In the process of EU constitutionalisation polity-building and constituency building cannot be meaningfully separated from each other. The making of a constitution is the prime example of wilful redesign of polity-society relations. It therefore addresses not only institutional actors and rule-making bodies in their quality as the EU's potential polity but also addresses collective actors, citizens or ordinary people in their quality as the EU's potential social constituency. Or to put it in the words of Tarrow: 'if polity building is occurring in Europe today, it must be seen not only at the summit but in the relations of contention and alignment at the intersection of elite and mass, local, national and supranational actors and institutions’ (Tarrow 2003: 2). European constituency-building indicates this other side of European polity-building. It refers to all kinds of concerns, claimsmaking and collective actions that are mobilised (or simply articulated) in relation to European governance. It further refers to all kinds of public expectations, opinions and attitudes that are shaped in the actors' daily experiences with European governance. It thus evokes the idea of an emerging European civil society in the classical sense of the term, as a particular kind of social interaction and communication that is, first of all and most elementary, different from the state (or the EU governing arrangement) and the market. 
Constitutional debates, and this is the neglected subject of research, are not simply about constituting the EU-polity; they are also about constituting the European political society. In normative and institutional terms, constitution-making is analyzed as a process of deliberation and reasoning over the kinds of desirable institutional-constitutional designs of the EU. The constitution is then seen 1) as a mechanism for influencing and controlling policies, and 2) as a mechanism for determining the shape of the polity (i.e. through institutional designs and procedures). Not developed in this traditional account is the possibility for constitution-making also to be shaping the social imagination of the polity, the kind of reflexivity that does not only inform the governing institutions but also the selfconception of the public as a political community, steeped within a polity.

The experience of constitution-making thus points to a different role of the public sphere in which constitutional debates unfold. As Craig Calhoun recently reminded us: 'To see the public sphere entirely as a realm of rational-critical discourse is to lose sight of the importance of forming culture in public life, and of the production and reworking of a common social imaginary’ (Calhoun 2003: 257). ${ }^{5}$ Constitutional debates trigger off an additional dynamic within the European public sphere as an 'arena of cultural creativity and reproduction in which society is imagined and thereby made real and shaped by the ways in which it is understood' (Calhoun 2003: 249). The public sphere that accompanies constitution making becomes an arena of societal self-description and self-imagination (Luhmann 1996; Marcinkowski 1993). Constitutional debates simulate this political society as a collectivity of collective decision-making and self-determination - in other words: As a democracy (Nassehi 2002).

This brings forth two critical issues with direct purchase on the European context. First is the need to define the mechanisms that make such an imaginary unity of the polity and the social constituency likely. Second is the adaptation or translation of this framework onto 
the European Union, precisely because of the Union's complex character and democratic deficit. Complexity here may entail significant differentials in the extent and scope of constitutional debate, amplified by ambiguity and contestation as to the very character of this entity. These issues are sufficiently serious as to require us to revisit not only the question of entity but also what kind of legitimacy such an entity can claim in the first place.

\section{The question of the legitimacy of the EU social and political order}

A core component that links polity and social constituency is legitimacy. Political legitimacy refers to popular approval and to the way in which public authority is justified. Such justifications open a basic communicative relationship between political authorities and their constituent publics. This replicates a basic sociological insight that the exercise of political power in modern societies can no longer be derived from a given and stable ('divine’) order. Political legitimacy stems instead from a contingent societal order that places substantial constraints on the exercise of political power. The legitimatory requirement thus binds any form of exercising political power back to society. In modern political orders, rule makers and those who are and feel affected by the rule (the polity and its social constituency) stand in a functional relationship to each other.

The concern with the EU's democratic deficit is evocative of the notion of the EU as a political entity that is very much in search of legitimacy (Eriksen and Fossum 2004). In practice, this means entering a communicative process of justification and reason giving with society. For the European Union, an entity which subscribes to democratic principles (also applied unto itself) there is no other source of legitimacy than society. The democratisation and constitutionalisation of the EU are therefore independent of the good-will of the rulers; it is a functional requirement for the Union as a system of European governance (Trenz and Eder 2004). 
The distinction between output legitimacy and input legitimacy (Scharpf 1999) refers to different degrees and ways of involving such a society. In the first, output, case, legitimacy is simply derived from the performance of European governance that must be made visible to the general but silent public. In the second case, legitimacy is derived from procedures that include the public voice in rule and decision-making. The first 40 years of European integration have revealed the insufficiency of a type of rule making that is based on mere output legitimacy and also how frail the 'permissive consensus' of the 'silent public' is. Discontentment with the present state of affairs and its deficits in terms of legitimatory procedures and outputs, have essentially compelled EU actors and institutions to raise the standards of legitimacy. If we look at the more recent EU treaty provisions, policy documents, and EU officials' speeches, we find that the relevant standard is that of democratic legitimacy. The EU constitution making process has started from this new consensus on the need to democratise the EU and to base it on a specific form of justification in line with the generally approved normative principles of a democratic social and political order (Habermas 2001; Eriksen, Fossum and Menéndez 2003, 2004).

This new and common sense commitment to democracy is a remarkable achievement for an entity with roots in international law. What is even more remarkable is that the EU has committed itself to a direct and independent form of democratic legitimacy that cannot be derived from the Member States in their quality as democratic nation-states. Conceiving the emerging EU-polity in democratic terms can only mean that the EU also has to enter into a direct relationship with its own social constituency.

This commitment to legitimacy is the central parameter that guides our research efforts. The EU is a polity that has entered the process of democratization, but there is no doubt that it lacks some of the basic prerequisites for democracy. This issue is complicated by the complex, novel and still-in-the-making character of the EU. As noted, it is not a state, nor 
would the CT, even if it had been fully adopted, make it into a state. The EU is not held together by a genuine public sphere neither can it draw on the solidarity and identity of a unified demos. It is nevertheless confronted with expectations of democratic legitimacy and with claims for participation, membership and belonging.

These observations underline that the legitimacy problem must be addressed not only through normative-institutional model building, but also through developing an understanding of the social dynamics of legitimation and delegitimation in the interplay of conflicting actors/institutions and their relevant publics. Theoretically speaking, this means to turn the 'people(s) of Europe' from a black box into a socially structured phenomenon, and one that is open to sociological analysis. ${ }^{6}$ Empirically speaking, it entails investigating the social dynamics of contention and claims-making within an unprecedented social-institutional setting.

\section{Between silence and voice: The EU's social constituency in the making}

The EU's social constituency certainly in its present shape is not an entity or collectivity that can be described in terms of membership, nor in terms of sharing particular cultural characteristics and identities. It takes various organisational forms that emerge out of the structural relationship (the ongoing processes of communication and interaction) between EU multi-level governance and the ‘ordinary people’ (Tarrow 2003). These ‘ordinary people’ include all those who feel in some way affected by European governance either as silent or attentive publics, or as collective actors who begin to mobilise their concerns (Trenz and Eder 2004).

Two terms can be used to capture the social constituency. European civil society refers to the possible relationship between the emerging EU polity and its social constituency. Empirically, this is translated into voice which opens up a dynamic of legitimation and delegitimation of the EU's institutional arrangement and its concrete output in terms of 
policies. According to this conception, the EU's social constituency is conceived of as the 'voice of the people', that is, articulated as the sum of formal and informal procedures of negotiation and collective decision-making in particular institutional settings, across different sectors and territorial scales. The notion of European political society relates to the possible unity of the EU polity and social constituency. Empirically, this is translated into the reflexivity of constitutional debates which sets off a dynamic of identity constructions and results in a particular form of discourse about the 'unity in diversity' of the European social and political order (Trenz forthcoming). According to this conception, the EU's social constituency is conceived of as the 'collective representation of the people', which tells us what the Europeans have in common.

In line with the above we propose an analytical model that considers European constitution making in relation to the broader process of creating and reshaping the imaginary unity of a European political society; a society that encompasses a notion of polity in terms of governance arrangement, together with, and in relation to, a notion of social constituency in terms of civil society. The political society of Europe is 1) a structured relationship between the EU-polity and its social constituency (the former perceived as governance in terms of collective decision making capacities and the latter perceived of as civil society that supports or challenges governance); and 2) the imagination of the unity of diversified governance structures and diversified social constituencies.

Our sociological model of European constitutionalisation is thus built on the notion of the reflexivity of communicative processes which address the problem of the unity of Europe's social and political order. That such communication takes place is implicit in the basic notion of European constitution making which is about renegotiating the legitimacy of a new kind of social and political order. ${ }^{7}$ The reflexive moment of constitution-making originates in the search for a unitary, unique and legitimate European order that is distinct 
from the existing order of European nation states. Reflexivity can be further advanced by the exceptional character of European constitution-making which can be most appropriately described as a kind of second-order-constitutionalisation of multiple polities which are already constituted and not necessarily disintegrating.

The EU's social constituency is perceived either as the structure of public demands and expectations that are placed upon the EU, or in terms of the collective representations and social imaginations, that are produced as reflexive outcomes in debating the democratic legitimacy of the EU. This means that we can take account of the role of the people in Europe in two ways:

1) Voice which is either affirmative or critical, thus opening a dynamic of legitimation and delegitimation in relation to EU governance and polity building. The articulation of voice takes place in the form of putting claims and demands on the EU. This must take place in the public sphere (as opposed to lobbying or private governance), and voice must be addressed directly or indirectly to EU governing institutions. Constitution-making can then be analyzed as a single opportunity for voicing that structures a particular mode and particular contents of claims and demands. The most blatant form of measuring the voice of the people in the EU-constitution making process takes place through referenda, which confront the 'no' and 'yes' voters of a given and pre-established social constituency. More subtle forms of measuring the voice of the people refer to studies of participatory patterns, political mobilization, or public claims-making in the media that encompasses the whole constitution making process (and not only ratification).

2) Silence which exhibits ambivalence with regard to the legitimatory inputs into the EU political process. There can be no doubt that the old permissive consensus helped to establish the output legitimacy of the former European Communities. In terms of 
democratic legitimacy, however, silent publics are awkward, as they testify to a lack of enthusiasm on the part of people to become engaged and to identify with the new polity. Even during times of constitution-making, we have to take into account that the majority of the potential Europeans (those who are addressed by their governing institutions) opt for silence. For obvious reasons, we do not know much about the empirical reality of silent publics. One frequently used possibility is to measure silent publics through opinion polls (such as Eurobarometer). In the following we identify additional mechanisms for how to include silent publics in the analysis, through ways of studying collective representations of the EU's social constituency.

The question this distinction raises is why the silent public should be considered as a part of the EU's social constituency as well as how it can be meaningfully addressed and made sense of.

The first reason refers to the ambiguous status of the very notion of permissive consensus within a context of constitution-making, amidst already constitutionalized nationstates. Note that the founding Treaties of the European Communities were grounded on the common national constitutional traditions of the Member States, albeit in a fragmentary and unsystematic manner. This nevertheless helped to set up the conditions under which courts, and very especially the European Court of Justice, were implicitly assigned with the task of clarifying the normative implications of such common constitutional traditions in the concrete political and economic context of the process of European integration (Fossum and Menendez 2005). This meant that the new construction at least to a certain degree could draw on already justified norms. This by implication complicates how we may interpret silence in political legitimacy terms because it suggests a profound ambiguity in the ensuing European social imagination: people are asked to imagine an order that encompasses the core principles we associate with a democratic-constitutional polity but as situated and as transformed to suit a 
non-state, non-nation entity. What this transformed entity will look like is not properly explained.

Furthermore, studying silence helps us to counter more or less acknowledged biases in the social context, as well as in the framing of research. As Claus Offe has noted, each society has a "“hegemonic" configuration of issues that seem to deserve priority and in respect to which political success or progress is primarily measured, while others are marginal or “outside” of politics’ (1987: 66). It is in this connection important to establish where those that are silent can be seen to locate themselves within such a distinction. A related reason refers explicitly to the conceptual lenses we as analysts adopt. As Axel Honneth has noted: A critical social theory that supports only normative goals that are already publicly articulated by social movements risks precipitously affirming the prevailing level of political-conflict in a given society: only experiences of suffering that have already crossed the threshold of mass media attention are confirmed as morally relevant, and we are unable to advocatorially thematize and make claims about socially unjust states of affairs that have so far been deprived of public attention. (Honneth 2003: 115-6)

The underlying problem here is that there is no one-to-one relation between noise and contention on the one hand and suffered pain and injustice on the other. Resourceful actors may more easily and forcefully pursue struggles for recognition than weak and marginalised ones. The silent ones may be the worst sufferers. When placed within the cacophony of contending voices that a profound recognition struggle produces, the contentious action methodology offers very limited assurance that the researcher would pick up on the suffering silent or dispossessed. Here we see an obvious limitation in the contentious politics approach. A systematic approach to the study of silence may serve as an important safeguard against these problems. 


\section{Observing the EU social constituency: a research programme}

Within the 'nation-state containers' the social constituencies of claims-making were only exceptionally problematised, and contentious politics unfolded as distributive struggles within a constituted polity. Today, claims-making activities open up to new horizons that increasingly transcend the nation state. ${ }^{8}$ In addition to this we observe the unfolding of a new constellation of political culture which is thought of more in recognition than in redistribution terms. ${ }^{9}$ The two processes converge in the emergence of an increasingly transnationalised politics of recognition, with possible systemic effects: 'The increased prominence of the politics of recognition is one key indicator of movement beyond the Westphalian era' (Linklater 1998: 32). A new status politics that is unfolding within transnational institutional contexts underlines the need to conceive of collective actors as constituents of a new polity rather than merely as claimants within existing polities.

Our starting assumption is that social constituencies can be identified through the particular constellations of voice and silence of the multiple publics in relation to the EU constitutionalisation process. A major challenge is how to demarcate the relevant social constituency. Is it the present 25 Member States? Or is it the states that are explicitly affected by EU norms? If so, that would include not only the 25 Member States, but also the 3 affiliated states (EEA), a range of associated states/applicant states and perhaps even a number of would-be applicants (consider for instance Ukraina). A further differentiation refers to ‘core Europeans’ and ‘peripheral Europeans’ with regard to which voice and silence obviously takes quite different meanings (Eder 2005).

There is obviously no objective and compelling answer to this problem of demarcation, since the struggles for membership and recognition are part of the dynamic of how the EU's social constituency comes into being and undergoes constant transformation. This definitorial issue simply underlines the lessons from the globalisation and 
transnationalisation literatures: the question of who are the social constituents of particular policy arrangements has gained added importance within a changing political constellation of intensified transnational, supranational and transcultural interaction and communication. Complex processes that are generally labelled as ‘globalisation' combined with our specific case of ‘Europeanisation' have decoupled polities and social constituencies. They have thus reinvigorated an old and vital question, which had thus far seemed to be solved within the nation-state context: what are the sources and the limits of political membership?

European integration is linked to identity politics, in which the legitimacy of a new type of political entity is negotiated and in which claims-making activities unfold in relation to polity and constituency building processes. In line with this, we propose an encompassing research programme on EU-constitutionalisation that examines the following interrelated aspects:

- Legitimacy: What are the modes of legitimacy that the EU seeks to propound and comply with?

- Voice and Silence: What is the nature of the structure of demands and expectations directed at the EU?

- Collective representations: what are the reflexive modes of self-representation of the EU as a political community?

The unique character of the EU as a non-state polity prompts attention to the set of standards for democratic and legitimate governance that inform its multi-level institutional framework. When we compare the democratic standards that the EU appeals to with how the EU is made up, we find a deep standards-practice gap. Precisely how deep the gap is depends (a) on the precise character of the standards; (b) on the type of entity that the EU is and how well-suited such an entity is to put democratic standards into practice; and (c) in what direction the EU develops. If for instance the ratification process is abandoned, the commitment to further 
constitutionalisation may abate and the EU may revert to a more limited-type entity. It is also possible that the commitment to democracy at the EU level has been not much more than window-dressing. Therefore, to properly establish which mode of legitimacy that the EU seeks to comply with we have to go beyond formal arrangements and look at actual performance.

For an entity-in-the-making such as the EU an equally important issue pertains to whether the EU’s claims to legitimacy are consistent with citizens' demands on and expectations from it. Constitution making is a particular opportunity structure for mobilisation and it is important to understand collective actor constellations and the types of claims and demands put forth by them.

\section{Classifying justifications and modes of legitimacy}

The point of departure for the intermediation between polity building and constituency building is the historical prerequisite of a public sphere as the intermediary realm of communication and reasoning between authorities and free and equal citizens (Habermas (1989[1962]). All claims that are raised within the public sphere must be justified, taking account of the presence of a general (constituting) public. This linkage between claims and justifications will be used in the following to provide answers to the question of the legitimacy of the EU that is challenged or supported by claims-making. For this purpose, justifications can be classified according to three conceptions of rationality corresponding to three modes of legitimation, which again refer in rough terms to three types of entity (Eriksen and Fossum 2004: 438): 


\begin{tabular}{|c|c|c|}
\hline Conception of rationality & Mode of legitimation & Type of entity \\
\hline Instrumental & Efficiency/interests & Problem-solving entity \\
\hline Contextual & $\begin{array}{c}\text { Collective self- } \\
\text { understanding }\end{array}$ & $\begin{array}{c}\text { Value-based } \\
\text { community }\end{array}$ \\
\hline Communicative & $\begin{array}{c}\text { Justice and norms of } \\
\text { fairness }\end{array}$ & $\begin{array}{c}\text { Rights-based } \\
\text { community }\end{array}$ \\
\hline
\end{tabular}

From Eriksen and Fossum 2004: 438

These modes of legitimation are linked to different governance/government options, and hence provide different answers to the question of the legitimacy deficit of the EU and to the question of efficiency and governing capability. They may also be seen as different paths of institutional development with distinctive answers for how the EU is to handle its legitimacy deficit.

The first option is premised on an economic notion of legitimation. It depicts an enlarged EU that, instead of clarifying and addressing the question of identity and democracy abandons all constitutional aspirations and opts for a looser organisational form that emphasises regulation and binding economic co-operation. This type of organisation is based on an economic-utilitarian mode of thinking. It comes close to the notion of the EU as a special purpose association of functional integration. According to this mode of thinking, the EU is best conceived of as a functional type of organisation whose purpose it is to promote the material interests of the Member States. Such promotion may best be ensured by means of intergovernmental rather than supranational institutions. This notion of legitimation envisages citizens as producers and consumers. It is conditional, as it cannot draw on anything but actual performance. The relevant social constituency is narrow: voice is restricted to problem-solving in functional domains, or to actors who consider their relation to, and involvement with, the EU in utility terms, through the calculus of costs/benefits. The silence of the majority can be seen either as the expression of a permissive consensus or as the indifference of a public that has not developed any particular interest in the EU. 
The second option is based on a value-based notion of legitimation. Here the EU's emergence is depicted through the lens of a collective process of self-interpretation, based on a republican-communitarian reading of democracy. Constitutionalisation is a process whose foremost task is to clarify: Who are the peoples of Europe and who do they want to be? In this perspective the EU is a geographically delimited entity but one which has not yet fully discovered a common identity which can serve as the basis for developing stable goals and visions. One prominent possibility is to revitalise Christian and humanist values, which can serve as the foundation on which to develop a deeper sense of unity and community. The ultimate objective of such a strategy is to establish a we-feeling, and a sense of brotherhood and sisterhood required for a European demos. It is this sense of common destiny, a common fate induced by common vulnerabilities that turns people into compatriots who are willing to trust each other, to take on new collective obligations and to agree to redistributive practice. The relevant social constituency is broad: voice encompasses all those who speak of the Union as a value community and propagate the values that the European Union espouses. Voice is further relying on silent but attentive publics which are ready to receive the message and to be included within the boundaries of this value community that sets out who are Europeans and who are not.

The third option is based on the recognition of the need to continue the process of institution building at the political level. The main task of constitutionalisation is to help establish a Euro-democracy. In this perspective, a wider cosmopolitan conception of democracy is in operation. The presumption is that the spectre of popular opinions - emanating from broad public debate (European as well as non-European), transnational movements, (I)NGOs) and supranational and international bodies of norm enforcement - sway decision-makers to ensure the democratic legitimacy of their actions. Decision-makers face the people as rights holders who are not only cognisant of their entitlements (and obligations) but who also mobilize and act to ensure their enforcement. This option presupposes ongoing attention to constitution-making to establish a set of 
principles that provide the entity with legitimacy. The silence of the public must thus be overcome by enhancing the knowledge, capabilities and rights of European citizens. The relevant social constituency refers to the voice of EU-constituted and self-conceived rights-holders, who approach the EU as a granter of rights and concomitant obligations, and who seek to ensure that the rights the EU espouses also actually influence their lives and actions.

The above matrix can be used to develop the classificatory scheme of claims-making in the EU-constitutionalisation processs. The questions will be: what kinds of actors typically promote what kinds of justifications for what kinds of claims expressing their preference for what kind of political entity?

\section{Categorising the voice and the silence of the public}

\section{The spaces of contention}

To address the question of the 'voice' and the 'silence' of the European social constituency it is necessary to establish an overview understanding of the scope and character of public communication and contention that are related to the EU. Research on collective action and mobilisation have noticed a shift from social movement organisations and protest action to a more structured and cooperative approach that includes civic actors and institutions as partners and not necessarily as opponents of EU governance (Marks and McAdam 1999; Eder 2001; Trenz 2001). From this, the space of European contention could be related to changing political opportunity structures at the local, national and supranational levels outlining the contours of organised civil society in Europe. ${ }^{10}$

Constitution making can be construed as a particular political opportunity structure (POS) that motivates and channels a specific form of claims-making. Such an analysis should start with describing the relevant ascriptive containers that may prompt people to act and to identify. ${ }^{11}$ This would help avoid the pitfalls of existing research designs, which either look at 
only one particular category of actors (e.g. social movements, NGOs) or concentrate on only one specific sector of claims-making and interest formation (e.g. agrarian policy). ${ }^{12}$ The underlying categories of claims-making in the EU can thus be derived from the kinds of concerns and demands that are put forward and mobilised by all kinds of relevant actors. The underlying networks of claims-making are derived from the various relationships between and among claimants and addressees of claims-making in the EU and the particular kinds of actions and interactions that occur between and among them. Finally, silent publics can be related to these various categories and networks of claims-making in terms of representative relationships (or discrepancies in representation).

Developing a proper understanding of the impact of the media public sphere speaks to another neglected subject in research about the prospects for constitutionalising a new kind of social and political order beyond the nation-state. The basic assumption that constitutionalisation is based on the interrelation between polity-building and constituency building presupposes such an intermediary space. Media are the general amplifier of voice and it is only through the media that voice can resonate in the silent publics. The obvious problem of EU second order constitutionalisation is that constitutional debates cannot rely on a uniform media system. Voice and silence must be located instead within a highly diversified media sphere where different publics are addressed; creating different kinds of resonance.

The existence of a diversified European media system means that there might be unequal conditions for public claims-making across the European space. Media in one context might be open and sensitive to European constitutional issues; media in other contexts may be hostile or indifferent. Moreover, actors from one national context might have difficulties in getting access to different media. The type of media thus affects the processes and outcomes of constitutional debates in various ways. This becomes most obvious during times of 
referenda, when media actively shape the knowledge and the attitudes of the electorate, and thus become decisive for the overall fate of the constitutional project.

Existing research on the emerging European public sphere has highlighted that national media systems are increasingly penetrated by forms and dynamics of European political communication. In the Europub project funded by the Commission FP 5 (2001-2004) the scope of European claims-making in the media with regard to single selected policy fields was tested out as an indicator of different degrees of Europeanisation of national public spheres (Koopmans and Statham 2002). Complementary findings were delivered by Trenz (2004) on the general visibility of Europe in the media and the full range of political issues discussed. Future research on the EU's social constituency should not only focus on media discourse, but should also turn the media organisations themselves into the object of analysis. Research therefore has to pay attention to how the peoples of Europe form publics out of different media systems and how these media, in turn, shape public knowledge, attitudes, perceptions and identities.

\section{The phases of contention}

Constitution making within a democratic context is a particularly important occasion wherein the social constituency is asked to envision itself as a public and as a political actor. Constitution making also lends itself to such study in more practical terms, as the process is delimited in time and scope. A classical case of a constitutional moment (as depicted for instance by Bruce Ackerman 1991, 1997) is triggered by a signal and unfolds in several stages. For our purposes, to understand the social constituency effects of such a process, it is necessary both to understand the character of the signal and of the structuring of the process, that is, which institutional arenas, actors and publics that the process sets out to, and actually, activates. These factors are important in shaping the patterns of 'voice', and the particular 
constellation of voice and silence that unfolds throughout the process. Note that a democratic constitution making process relies on voice.

But a constitutional moment, even though delimited in time is not only about voice; it is also about silence, as the process activates and deactivates people through different stages. The process is such structured as to make it unfold according to a particular constellation of voice and silence. To get at this we can start with the stages of a model-type deliberative constitution making process (Fossum and Menendez 2005). This conception of the process is consistent with the third mode of legitimation outlined above, and is set up with five phases: (a) signaling; (b) initial deliberation; (c) drafting; (d) substantive deliberation; and (e) ratification. ${ }^{13}$ The different stages of the constitution making process open up and close down access to various types of actors at the different stages of the process. For instance, the signalling moment can be an entirely top-down initiative, whereas the initial deliberative phase is intended to elicit voice, that is to serve as a test of the strength of the social support of this initiative and as such should include both general and strong publics. ${ }^{14}$ The drafting phase is more closed and would normally include a strong public.

The point is that to understand the social constituency effects of constitution-making, we need information on the structuring of the process, including information on the institutions that serve as access points for claims-making (such as national parliaments and the European Parliament). This will help us to better understand the role of European institutional actors as facilitators and promoters of the EU's social constituency, and their possible effects on the perceptions and representations of the EU as a legitimate order (according to the models outlined above). Parliaments are 'strong publics' where claimsmaking takes a different form and where participating actors assume different roles bound to institutional constraints. Given that the process is such structured as to contain widely different degrees of access for the public as the process unfolds, it is also important to 
understand at what particular moments the media come in, how the media agenda-setting is brought about, and the effects that this has.

In voice terms ratification is the critical phase because public debates intensify and address the broader public. In some contexts people are given a direct voice that matters for the success of the overall process (as was clearly seen in the French and Dutch referenda cases). Media attention is therefore expected to be highest in the ratification period. This is a kind of contradiction, because ratification is no longer the period for claims-making to influence the shape and contents of the constitution. The social constituency therefore has only a limited role that is restricted to 'Yes' and 'No', but cannot propose amendments to the constitution. The paradox is that the moment of highest public attention is at the same time the worst moment for voicing substantive concerns. This also serves to underline that social constituency formation is not foremost about influence but about legitimacy, visibility, access and symbolic representation.

Even at the ratification stage the procedure matters for how much voice is elicited. Voice opportunities vary with ratification option. To illustrate different degrees of eliciting voice, consider the following five ratification options:

a) a polity-wide referendum only (types of majorities: super-majority vs. qualified majority vs. simple majority)

b) polity-wide referendum combined with strong publics ratification (where one option is a simple majority in the referendum combined with a certain percentage of strong publics endorsing the proposal)

c) referenda in critical constituencies only - combined with strong publics endorsement

d) parliamentary ratification (EP)

e) national ratification (with selected referenda, with prior elections, or without prior elections

The first two options are set up to elicit an explicit European voice, whereas the latter address Europeans in their capacity as nationals. 
The opportunity for voice within each ratification option must also be understood as linked to mode of legitimation. Out of the ones outlined above (the first instrumental mode of legitimation links up with options e and d for ratification; the second identitarian mode of legitimation links up with options c, b, a for ratification; and the third cosmopolitan-right based mode of legitimation links up with options a and b for ratification). Official choice of strategy (legally or politically determined) is therefore also a powerful cue as to the type of social constituency that is sought evoked during the process.

The EU’s Member States have chosen a wide multitude of ratification strategies. This is suggestive of a highly differentiated signal. How differentiated this is throughout the process becomes evident when one goes through the stages and looks at how they unfold within each member state as well as studies their cross-constituency resonance. The signal is no doubt differentiated; but the effect need not be so, because of cross-constituency resonance. Here voice and legitimacy do not cohere: the fact that the process is so unequally structured has legitimacy implications, as those constituencies that hold referenda claim to be speaking in the name of those that do not. In turn, negative results in some national constituencies feed back into the process as ambiguous signals, which offer great temptations to respond in a partial, piecemeal way which again helps fragment the process and the social constituency signal itself.

\section{The silence of the public}

The basic assumption that has guided our research on the EU's social constituency so far is that European constitution-making opens up an arena of contention in which different collective actors and institutions step forth and mobilise particular interests and concerns. The EU's social constituency is thus perceived as a kind of interactive relationship and communicative network of those that raise their voice in the public sphere. This is a pragmatic 
approach to doing research because it presupposes actors who through their voice produce the empirical reality that can be recorded directly by the scientific observer. Against this scientific pragmatism, we want to highlight that the public sphere has always been conceptualised as a triangular relationship between those who communicate in the public arena (A and B in their role as speakers and respondents) and the silent publics $\mathrm{C}$ as those who attend communicative interactions but for the moment decide not to intervene (Gerhards and Neidhardt 1991; Neidhardt 1994). This implies a changing focus on the public sphere not as a relationship of direct communicative exchange (this would only describe what is going on in the political arena) but as an observatory relationship that includes communicating actors and their publics. In the European framework, these structured observatory positions have to be redefined. This implies the necessity to focus on the role of the silent publics in relation to European governance and constitution making.

The silent public cannot be analysed that easily because it escapes usual indicators of social research. Silent publics remain rather invisible and do not leave many traces that can be observed empirically. We encounter them only occasionally, for instance, on occasion of constitutional referenda with high abstention rates. Yet it is difficult to conclude from abstention in referenda to the character of particular groups in society and their expectations with regard to the EU. Silent publics are heterogeneous and amorphous entities and not a group or collective actor that can be described through its structural elements (Neidhardt 1994). They are constituted precisely by the fact that they do not take action and do not organise. At best, silent publics as part of the EU’ social constituency stand in an observatory relationship to the EU and can be measured by the different degrees of attention they pay to European politics (Stichweh 2002: 59).

Public opinion surveys are the classical research instrument to measure the expectations of the silent public. With the Eurobarometer, social science has a detailed and 
fairly reliable data source at its disposal for measuring the attitudes of European citizens over time and across the European space. Over the whole process of constitution-making, special Eurobarometer surveys are available with detailed information on citizens’ knowledge, opinions and preferences about the CT. Such data can be used to determine to what degree the populations in the Member States are ready to support European integration and to what extent they have developed patterns of European belonging and identity (Kohli 2000). With regard to constitution-making, Eurobarometer surveys showed that more than two thirds of European citizens supported the general idea of an EU-constitution (with a clear dominance of negative votes in the UK and in Denmark), but only a minority of 49 per cent was actually willing to vote in favour of the draft Constitutional Treaty. ${ }^{15}$ However, this generally positive attitude is not linked to clearly expressed preferences. General knowledge of the contents of the constitution and of the procedures of constitution making is very low and a substantial segment of the population remains undecided. ${ }^{16}$

Public opinion polls replicate the contours of the silent public that would otherwise remain entirely invisible (or visible only through its positive or negative effects in general elections). The problem is that such opinions and attitudes as measured through Eurobarometer have a highly constructed character. They measure opinions in the highly artificial context of the survey that would not exist without the survey question. The silent public is thus an artificial construct of the measuring instruments of scientists who are again commissioned by European institutions. From our perspective, this constructed character points to a different function of the Eurobarometer: opinion polls have become an institutionalised form of observing silent publics through EU policy actors. The detailed character of many Eurobarometer surveys points to the strategic relevance of such data for the EU-institutions to provide them with feedback and orientations that are needed for 
legitimating their particular choices and decisions. The political function of Eurobarometer data is thus to give silent publics a voice that can be included in the policy-making process.

A further argument that underlines the urgency for a shift in the research focus is the biased and selective character of voice in the EU that is seriously restricted by the mobilising capabilities of particular groups. Our concern is that voice in EU constitution-making is linked to old and new inequalities that are reproduced in the European realm. One possibility to check whether there is a link between silence and suppression, marginalisation, and discrimination, is to develop a kind of meta-map of Europe’s relevant social dimensions, which contains data on the categories of people that are most likely to be discriminated against and then to hold this up against information on contentious and silent publics. ${ }^{17}$ National statistics and demographic data usually build on similar categories (minorities, religion, class, sex or age) and can thus be systematically analysed for testing out possibilities for the socio-demographic localisation of silent publics in relation to European integration. ${ }^{18}$ As a starting assumption we may assume that silent publics relate to particular stratifications and cleavage lines and can thus be located in similar socio-structural positions across the Member States. From a critical perspective, one possible outcome of European constitution making could be the intensification of the struggles between what Bauman (1998) calls 'globals vs. locals', ‘inside vs. outside’, 'here vs. there', 'near vs. far away’, 'margin vs. center'. If this is the case in the European sphere, this could lead to the reification of a new class bias between an elitist highly educated, mobile Europeanised (or cosmopolitan) new bourgeoisie as the included voice and a localised, immobile and traditional proletariat with a low educational profile as the excluded silence of the EU' social constituency. Universalistic/European attitudes and particularistic/nationalistic attitudes would thus increasingly become an indicator for class. To establish whether there is such a possible class 
bias in the support and opposition to European integration needs further research attention (Favell forthcoming).

Such a broad research agenda raises many questions pertaining to the sources, the character and the availability of relevant information; the nature and range of relevant actors; and the relevant contexts that have to be researched. The socio-demographic mapping of the EU's social constituency in terms of voice and silence is no easy task in practical terms and further also raises important ethical questions. ${ }^{19}$

This approach however sensible in public policy terms can also be seen as an imposition on individual autonomy. Hence, several of the EU’s Member States have data protection provisions that prohibit against the processing of personal data on some of the categories of people (racial and ethnic origin, religious beliefs and health and sex life) that are

most likely to be discriminated against. ${ }^{20}$ This makes it necessary to develop additional, less intrusive, methods for obtaining data on the relevant categories. A critical such source is again the media where silent publics leave their traces as the 'third' of political communication. The assumption is that public voice can be categorised not only according to the articulated claims and concerns but also according to the collective representations of silent publics that are needed as the background knowledge for orientation in the European space.

\section{Categorising collective representations}

In normative terms, voice must be linked to representative structures in order to be able to claim legitimacy. Such representative structures are taken for granted at the nation-state level, but are inadequately set up at the European level. Those that raise 'the European voice' implicitly speak on behalf of the silent publics because the latter figure as part of the justificatory strategies of voice. Voice is therefore not only linked to particular concerns but also to the general claims for representation of those who speak in the name of the public. The 
problem with inadequate representative structures is that the procedural mechanisms to check the veracity of such claims are inadequate.

In the following, we propose a model in which silent publics are included through claims for representation by those who raise their voice in European constitutional affairs in the name of the public. This points to a different dynamic of social constituency building through particular semantics, images and symbols, which are evoked as a by-product of voicing, and that speak to the constraints collective actors face when seeking to generalize their particular claims. Legitimation is perceived here as a process of generalizing claims, not as pertaining to particular actors and their interests, but to more encompassing groups and their identities. From this perspective, public discourse provides a specific offer of collective identifications as a form of self-reference and reflexivity of the discursive community. We can hypothesize that the public discourse on the constitutionalisation of the EU intensifies such identitarian dynamics of the self-imagination of the Europeans and their belonging. The debate on the conditions for democracy contributes to the particular identity of the community, that is, as one of collective self-determination.

Notably, our proposal to address the question of societal self-representation in relation to constitutionalization differs considerably from formal and substantial accounts of the need for, as well as the shape of, a European identity. The identitarian dynamic of constitutionalization that we want to outline is not something that has to be enshrined in the formal text of the constitution (e.g. through a reference to the Christian heritage as proposed by Weiler (2003) or through the identity symbols which EU institutions use in their external relations). What we say instead is that democratic practice, i.e. the practice of defining the conditions for collective decision-making and collective self-determination is linked to a reflexive process of identifying the very collectivities of democracy. 
With the Laeken Convention's explicit framing of the debate on the future of Europe in constitutional terms, Europeans entered a meta-constitutional debate which revolved around the very idea of Constitution at the supranational level, and as such also compelled Europeans to communicate about their shared past, their collective destiny and their future collective projects. Such a context also effectively forces Europeans to recognise each other as relevant to each other in daily practice, that is, as the reciprocal representation of the collective self in public communication (Eder 2005). The assumption is that the discursive practices wherein the Europeans negotiate the conditions of membership and recognition (and this is also what constitutionalisation is about) create a collective self with a sense of its particularity as the 'European people'. To the extent that such experiences are accumulated in the course of integration, a new type of European identity emerges which is based on the collective memory of institutionalised interactions of the past. The process of democratic spill-over triggered off by the EU constitutionalisation (Trenz and Eder 2004, 2005) is here turned into a process of identitarian spill-over that simulates the unity of the political society of Europe.

Such mechanisms of European identity construction can be systematically retraced in the opening spaces of contention among the Europeans (albeit as we noted with unequal manifestations, presumably in line with process differences). The research task here is to relate the landscape of interests to the images of the 'collective we' that are generated by collective actors as legitimatory devices in public discourse. The mapping of belonging would embrace several references to silent publics that are called upon through claims for representation of voicing actors (notably, this does not presuppose the establishment of representative structures). Collective identities could thus be measured in the communicative inputs of collective actors that respond to the normative constraints imposed upon them in the European institutional context. 
The question is further in how far the emerging and widening space of contention among Europeans creates its own sense of community. Such a basic sense of togetherness can be expected as a result of the ongoing experiences of problem-solving within a particular institutional context. Collective identity could thus be measured as the communicative output of the ongoing forms of public discourse among the participants who recognise each other as belonging to a particular group sharing a particular history, enduring a shared destiny and starting off towards a common future.

\section{Concluding remarks}

The main purpose of this article was to help set the research agenda for a broadened understanding of European constitutionalisation in relation to polity and constituency building. This opens a new perspective on European integration as societal integration beyond institutions and policy-making. Independently of the fate of the CT that was agreed upon by the Convention and the governments, but unequally received by citizens, the particularity of the constitutional experience of the EU consists in linking the nascent European society to democracy as a project of collective self-determination. A new social space unfolds for voice and for collective representations of what we call the EU's social constituency. This social constituency is in the making even without a formal constitution. The EU constitution-making process might experience major backlashes in polity building but it might still succeed in building a social constituency.

The new political order that has spread across most of Europe has greatly reduced the scope for exit for those who do not want to be bothered with Europe. This is likely also to affect the role and character of voice and loyalty (as expressed in silence). With constitutionmaking now also explicitly eliciting voice, a new constellation emerges in which the silence of the public can no longer be taken as a sign of tacit support and of the permissive consensus 
of the people. One possibility is that the option of silence is increasingly taken as an alternative to exit by those who lack capacities or will to raise their voice in European affairs. In the absence of voice, the silence of the public assumes a signalling function: silence 'speaks' of the possible alienation of the public, it 'speaks' of public indifference and it 'speaks' of latent concerns that can be easily turned into voice (e.g. on occasion of referenda). As such silence can also be used for manipulative purposes, by proponents and opponents alike. The public silence in constitution-making is thus no longer a supportive condition for institution-building but a risk and uncertainty built into the very process of constitutionalization.

The need for such research should be readily apparent. To understand the legitimacy of the emerging Euro-polity we cannot simply focus on how well the political-legal arrangements comply with normative requirements; we also need to understand the social take and acceptance of these processes. This is widely recognised but as we have sought to demonstrate this needs to be done through devising an analytical framework that is capable of capturing the dynamic interaction of voice and silence within this crucial stage of European integration. The EU might then not have a constitution in the short run. But it might have a social constituency that has raised its voice. The institutional-constitutional licence that this constituency is willing to offer to the Union is a key topic not only for the reflection period that was announced by the European Council but also for the future.

\footnotetext{
1 With constitution making we refer to the specific process of forging a constitution. With constitutionalisation is meant the larger process of polity formation, which includes actual operational rules, norms and institutions. Constitutionalisation can therefore entail the emergence of a material constitution, whether this is entrenched in a formal written document or not. For the distinction between formal and material constitution, see Eriksen, Fossum and Menéndez (2004).

${ }^{2}$ For institutional and normative analyses of the Convention process see Eriksen, Fossum and Menendez (2004), Magnette (2003); Maurer and Schild (2003); Wessels (2003); Pernice (2004); Peters (2004).

${ }^{3}$ Prominent critical voices are Grimm (1995); Scharpf (1999: 29ff.); Weiler (1999: 264ff.).
} 
${ }^{4}$ These include studies on the role of communication, public attitudes and collective identities (Norris 2000; Kohli 2000) as well as on civil society and collective action (Marks and McAdam 1999; Imig and Tarrow 2000; Ruzza 2004).

${ }^{5}$ Nancy Fraser makes a similar point and speaks about 'subaltern counterpublics' (Fraser 1992).

${ }^{6}$ See Abromeit and Schmidt (1998) and Weiler (1999: 269) for an early critique of this agnostic attitude that considers 'the people' only as an external constraint but not as an intervening variable in European politics.

${ }^{7}$ For analyses of the reflexivity of EU constitution making see Bohman (2004).

${ }^{8}$ This has been elaborated by authors such as Smith, Chatfield, and Pagnucco (1997); Keck and Sikking (1998); Risse (2001).

${ }^{9}$ The debate is either on the new framework of recognition (Benhabib 2002; Gutmann 2003; Honneth 1995; Parekh 2000; Taylor 1995) or on the new constellation of recognition vs. redistribution (Fraser and Honneth 2003).

${ }^{10}$ See Ruzza (2004) on advocacy coalitions in three policy sectors - environmentalism, regionalism and antiracism and Giugni and Statham (2002) on unemployment struggles.

${ }^{11}$ The literature on identity politics and recognition highlights gender, race, class, physical handicap, sexual orientation, age and nationality. Across Europe these categories will organise and mobilise but to greatly varying degrees

${ }^{12}$ People who belong to a category and organise to promote a particular group identity comprise both a category and a network, or what Tilly (1978) has termed catnet.

${ }^{13}$ Note that the other modes of legitimation listed above envision other ways of structuring the process.

14 Strong publics refer to institutionalised deliberations whose discourse encompasses both opinion formation and decision making. In institutional terms, strong publics alludes to parliamentary assemblies and discursive bodies in formally organised institutions imbued with decision-making power, yet constrained by the logic of arguing and impartial justification. See Fraser (1992).

15 See Standard Eurobarometer 62 (December 2004) and Special Eurobarometer 214: The Future Constitutional Treaty (March 2005).

${ }^{16}$ According to Special Eurobarometer 214: The Future Constitutional Treaty (March 2005) only 11 per cent of the Europeans have heard about the constitution and have some general knowledge of its contents.

${ }^{17}$ For an approach to how such can be constructed see Fossum (2005).

${ }^{18}$ Harmonising variables and measuring instruments of national statistics is itself a process of Europeanisation strongly supported by the Statistical office of the European Communities (Eurostat).

${ }^{19}$ For instance with regard to the sensitive issue of immigration and integration of immigrants, the EU has gained increased competence, and with this the need for common data has become obvious. CompStat is an EU-funded project whose aim it is to help obtain comparable knowledge on the status of and the general conditions for the integration of 'immigrant minorities' in the Member States. The basic pre-condition for this is comparability of statistical data and indicators: Without reliable and comparable knowledge about the forms and levels of integration of immigrant minorities in various spheres of society of each member state and without common benchmarks and evaluation criteria applicable in all Member States, it is impossible to devise an approach which is really 'common'http://www.compstat.org/Start/

${ }^{20}$ This pertains to Denmark, Finland, Sweden and Italy http://europa.eu.int/comm/justice home/cfr_cdf/doc/report_eu_2003 en.pdf. Practice varies considerably in the Union here. An examination on data on ethnic minorities in the Member States revealed that in Slovenia, for instance, the Constitution states explicitly that any person has the right to declare his or her ethnic affiliation.

\section{References}

Abromeit, H. and Schmidt, T. (1998) 'Grenzprobleme der Demokratie: Konzeptionelle Überlegungen’, in B. Kohler-Koch (eds) Regieren in entgrenzten Räumen, Politische Vierteljahresschrift, Sonderheft 29, Opladen: Westdeutscher Verlag. 
Ackerman, B. (1991) We the People, Volume I: Foundations, Cambridge, MA: The Belknap Press of Harvard University Press.

Ackerman, B. (1997) We the People, Volume II: Transformations, Cambridge, MA: The Belknap Press of Harvard University Press.

Bauman, Z. (1998) Globalization. The Human Consequences, New York: Columbia University Press.

Benhabib, S. (2002) The Claims of Culture. Equality and Diversity in the Global Era, Princeton: Princeton University Press.

Bohman J. (2004) 'Constitution Making and Democratic Innovation: The European Union and Transnational Governance’, European Journal of Political Theory 3(3): 315-37

Calhoun, C. (2003) 'The Democratic Integration of Europe: Interests, Identity, and the Public Sphere', in M. Berezin and M. Schain (eds) Europe Without Borders: Re-mapping Territory, Citizenship and Identity in a Transnational Age, Baltimore: Johns Hopkins University Press.

Eder, K. (2001) 'Chancenstrukturen für Bürgerbeteiligung und Protestmobilisierung in der EU. Überlegungen zu Einigen Besonderheiten Transnationaler Streitpolitik', in A. Klein; R. Koopmans and H. Geiling (eds) Politische Partizipation und Protestmobilisierung im Zeitalter der Globalisierung, Opladen: Leske and Budrich.

Eder, K. (2005) 'Remembering National Memories Together: The Formation of a Transnational Identity in Europe', in K. Eder and W. Spohn (eds) Collective Memory in the Enlarging Europe, Aldershot: Ashgate, forthcoming.

Eriksen, E. O.; Fossum, J. E. and A. J. Menéndez (eds) (2003) The Chartering of Europe: The Charter of Fundamental Rights and its Constitutional Implications, Baden-Baden: Nomos.

Eriksen, E. O. and Fossum, J .E. (2004) 'Europe in Search of Legitimacy: Strategies of Legitimation Assessed', International Political Science Review 25(4): 435-59.

Eriksen, E. O.; Fossum, J .E. and Menéndez, A. J. (eds) (2004) Developing a Constitution for Europe, London: Routledge.

Favell, A. (forthcoming) Eurostars and Eurocities: Free Moving Urban Professionals in an Integrating Europe, Oxford: Blackwell.

Fossum, J. E. (2005) 'Conceptualising the EU’s Social Constituency', European Journal of Social Theory 8(2): 123-47.

Fossum, J. E. and A. J. Menéndez (2005) ‘The Constitution’s Gift? A Deliberative Democratic Analysis of Constitution Making in the European Union', European Law Journal 11(4):382-412.

Fraser, N. (1992) 'Rethinking the Public Sphere. A Contribution to the Critique of Actually Existing Democracy’, in C. Calhoun (ed.) Habermas and the public sphere, Cambridge, MA: MIT Press.

Fraser, N. and Honneth, A. (2003) Redistribution or Recognition? A Political-philosophical Exchange, London: Verso.

Gerhards, J. and Neidhardt, F. (1991) 'Strukturen und Funktionen Moderner Öffentlichkeit. Fragestellungen und Ansätze’, in S. Müller-Dohm and K. Neumann-Braun (eds) Öffentlichkeit, Kultur, Massenkommunikation. Beiträge zur Medien- und Kommunikationssoziologie, Oldenburg: Universitätsverlag.

Giugni, M. and Statham, P. (2002) 'The Contentious Politics of Unemployment in Europe: Political Claim-making, Policy Deliberation and Exclusion from the Labor Market - A Research Outline’, European Political Communication Working Paper 2/02, Leeds: EurPolCom.

Grimm, D. (1995) ‘Does Europe Need a Constitution’, European Law Journal 1: 282-302. 
Guéhenno, J.-M. (1998) 'European Integration: The End of Politics or the Rebirth of Democracy’, Hessische Gesellschaft für Demokratie und Ökologie, available at http://www.hgdoe.de/pol/guehenn.htm.

Gutmann, A. (2003) Identity in Democracy, Princeton: Princeton University Press.

Habermas, J. (1989) [1962] The Structural Transformation of the Public Sphere, Cambridge, MA: MIT Press.

Habermas, J. (2001) 'A Constitution for Europe’, New Left Review 11: 5-26.

Honneth, A. (1995) The Struggle for Recognition: The Moral Grammar of Social Conflicts, Cambridge: Polity Press.

Honneth, A. (2003) 'Redistribution as Recognition: A Response to Nancy Fraser', in N. Fraser and A. Honneth (eds) Redistribution or Recognition?, London: Verso.

Imig, D. and Tarrow, S. (2000) 'Political Contention in an Europeanising Polity', West European Politics 23(4): 73-93.

Keck, M. and Sikkink, K. (1998) Activists Beyond Borders. Advocacy Networks in International Politics, Ithaca: Cornell University Press.

Kohli, M. (2000) 'The Battlegrounds of European Identity', European Society 2(2): 113-37.

Koopmans, R. and Statham, P. (2002) 'The Transformation of Political Mobilisation and Communication in European Public Spheres: A Research Outline’, available at http://europub.wz-berlin.de.

Linklater, A. (1998) The Transformation of Political Community, Cambridge: Polity Press.

Luhmann, N. (1996) Die Realität der Massenmedien, Opladen: Westdeutscher Verlag.

Magnette, P. (2003) 'Coping with Constitutional Incompatibilities. Bargains and Rhetoric in the Convention on the Future of Europe, Jean Monnet Working Paper 14/03.

Marcinkowski, F. (1993) Publizistik als Autopoietisches System: Politik und Massenmedien. Eine Systemtheoretische Perspektive, Opladen: Westdeutscher Verlag.

Marks, G. and McAdam, D. (1999) 'On the Relationship of Political Opportunities to the Form of Collective Action. The Case of the European Union', in D. della Porta; H. Kriesi and D. Rucht (eds) Social Movements in a Globalizing World, London: Macmillan Press.

Maurer, A. and Schild, J. (eds) (2003) 'Der Konvent über die Zukunft der Europäischen Union’, Synoptische Darstellungen zur Konventsdebatte, SWP Dokumentation, Berlin: Stiftung Wissenschaft und Politik.

Nassehi, A. (2002) 'Politik des Staates oder Politik der Gesellschaft. Kollektivität als Problemformel des Politischen', in K. U. Hellmann and R. Schmalz-Bruns (eds) Niklas Luhmanns Politische Soziologie, Frankfurt a.M.: Suhrkamp.

Neidhardt, F. (1994) ‘Öffentlichkeit, Öffentliche Meinung, Soziale Bewegungen’, in F. Neidhardt (ed.) Öffentlichkeit, Öffentliche Meinung, Soziale Bewegungen, Kölner Zeitschrift für Soziologie und Sozialpsychologie, Sonderheft 34/1994, Opladen: Westdeutscher Verlag.

Norris, P. (2000) A Virtuous Circle. Political Communications in Postindustrial Societies, Cambridge: Cambridge University Press.

Offe, C. (1987) 'Challenging the Boundaries of Institutional Politics: Social Movements Since the 1960s', in C. S. Maier (ed.) Changing Boundaries of the Political: Essays on the Evolving Balance Between the State and Society, Public and Private in Europe, Cambridge: Cambridge University Press.

Parekh, B. (2000) Rethinking Multiculturalism, Harvard: Harvard University Press.

Pernice, I. (ed.) (2004) Die Europäische Verfassung im Globalen Kontext, Baden-Baden: Nomos. 
Peters A. (2004) 'European Democracy after the 2003 Convention', Common Market Law Review 41(1): 37-85.

Risse, T. (2001) 'Transnational Actors, Networks, and Global Governance', in W. Carlsnaes; T. Risse and B. Simmons (eds) Handbook of International Relations, London: Sage.

Ruzza, C. (2004) Europe and Civil Society. Movement Coalitions and European Governance, Manchester: Manchester University Press.

Scharpf, F. W. (1999) Regieren in Europa. Effektiv und Demokratisch? Frankfurt a.M.: Campus.

Smith, J.; Chatfield, C. and Pagnucco, R. (eds) (1997) Transnational Social Movements and Global Politics: Solidarity Beyond the State, Syracuse: Syracuse University Press.

Stichweh, R. (2002) 'Die Entstehung einer Weltöffentlichkeit', in H. Kaelble; M. Kirsch and A. Schmidt-Gernig (eds) Transnationale Öffentlichkeiten und Identitäten im 20. Jahrhundert, Frankfurt a.M.: Campus.

Tarrow, S. (2003) 'Center-Periphery Alignments and Political Contention in Late-Modern Europe’, in C. Ansell and P. Giuseppe (eds) Beyond Center-Periphery, Cambridge: Cambridge University Press.

Taylor, C. (1995) Philosophical Arguments, Cambridge, MA: Harvard University Press. Tilly, C. (1978) From Mobilization to Revolution, N.Y.: McGraw-Hill.

Trenz, H.-J. (2001) 'Protestmobilisierung in Netzwerken. Revitalisierung oder Selbstblockade Zivilgesellschaftlicher Protestformen in der EU?', Forschungsjournal Neue Soziale Bewegungen 14(1): 87-98.

Trenz, H.-J. (2004) 'Media Coverage on European Governance. Testing the Performance of National Newspapers', European Journal of Communication 19(3): 291-319.

Trenz, H.-J. (forthcoming) ““Quo vadis Europe?” Quality Newspapers Struggling for European Unity’, in J. E. Fossum and P. Schlesinger (eds) One EU - Many Publics, London: Routledge.

Trenz, H.-J. and Eder, K. (2004) 'The Democratising Role of a European Public Sphere. Towards a Model of Democratic Functionalism', Journal of European Social Theory 7(1): 5-25.

Trenz, H.-J. and Eder, K. (2005) 'Prerequisites of Democracy and Mechanisms of Democratisation' in B. Kohler-Koch (ed.) Debating the Democratic Legitimacy of the European Union, Boulder: Rowman and Littlefield, forthcoming.

Weiler, J. H. H. (1999) The Constitution of Europe: Do the New Clothes Have an Emperor? and Other Essays on European Integration, Cambridge: Cambridge University Press.

Weiler, J. H. H. (2003) Un’Europa Cristiana, Milano: Rizzoli.

Wessels, W. (2003) 'Der Verfassungsvertrag im Integrationstrend: Eine Zusammenschau Zentraler Ergebnisse’, Integration 26(4): 284-300. 